\title{
Men and Women in Rice Farming in Africa: A Cross-Country Investigation of Labor and Its Determinants
}

\author{
Florent Mahoukede Kinkingninhoun Medagbe ${ }^{1}$, Shota Komatsu ${ }^{2}$, \\ Gaudiose Mujawamariya ${ }^{3 *}$ and Kazuki Saito ${ }^{4}$ \\ ${ }^{1}$ Economics and Sociology for Rural Development (ESRD), Faculty of Agronomic Sciences, University of Abomey Calavi, \\ Abomey-Calavi, Benin, ${ }^{2}$ Department of Agricultural and Resource Economics, The University of Tokyo, Bunkyo-Ku, Japan, \\ ${ }^{3}$ Africa Rice Center, Immeuble FOFIFA Ampandrianomby, Antananarivo, Madagascar, ${ }^{4}$ Africa Rice Center, Bouaké, Côte \\ D'lvoire
}

\section{OPEN ACCESS}

Edited by:

Ephraim Maduhu Nkonya, International Food Policy Research

Institute, United States

Reviewed by:

Alisher Mirzabaev,

Center for Development Research

(ZEF), Germany

Gabriel da Silva Medina,

University of Brasilia, Brazil

*Correspondence:

Gaudiose Mujawamariya

g.mujawamariya@cgiar.org

Specialty section:

This article was submitted to Land, Livelihoods and Food Security, a section of the journal

Frontiers in Sustainable Food Systems

Received: 12 December 2019

Accepted: 29 June 2020

Published: 07 August 2020

Citation:

Kinkingninhoun Medagbe FM, Komatsu S, Mujawamariya G and Saito K (2020) Men and Women in

Rice Farming in Africa: $A$

Cross-Country Investigation of Labor and Its Determinants.

Front. Sustain. Food Syst. 4:117.

doi: 10.3389/fsufs.2020.00117
Women make significant contribution to rice farming, processing, and marketing, but only have limited access to technical knowledge and technologies that can reduce their drudgery and labor bottlenecks, and provide them with additional income. Women also oversee the reproductive responsibilities. This paper comparatively investigates the role of women in rice farming across four countries (Burkina Faso, Côte d'Ivoire, Madagascar, Sierra Leone) by examining the labor time distribution and its resulting income for men and women. It also assessed the determinants of their labor inputs in different rice farming environments. Results show that women and men spend on average 1-3h per day in rice production, making 45-135 working days of involvement in annual rice cultivation. Looking into the distribution of labor input provision in productive activities, it is found that apart from the specific activity of rice parboiling, which is practiced in certain countries mostly by women, men are the ones more engaged in rice farming. The specific labor input depends on several factors including the farm size, time spent on non-agricultural activities, and access to production equipment. These results provide the first evidence to that women farmers do not necessarily spend more time than men in rice cultivation in Africa, as it is often assumed. Certainly, across countries and systems, and also within male and female farmers categories, there are heterogeneous labor inputs and associated determining factors and incomes. Male farmers earn higher income than female farmers in the different productive activities, except only for rice parboiling. This finding indicates that increasing labor input for rice would not result in higher income for female farmers. Female farmers might find better options in other agricultural activities such as food processing.

Keywords: labor, gender, sub-Saharan Africa, rice farming, gender roles, econometric analysis, percentiles

\section{INTRODUCTION}

Women constitute a significant resource in agriculture and the rural economy, as farmers, laborers, and entrepreneurs (SOFA Team and Doss, 2011). For long, it was claimed that women contribute $60-80 \%$ of agricultural labor in Sub-Saharan Africa [Food and Agriculture Organization of the United Nations (FAO), 1995] or generally that agricultural work force contains a larger share of women than men (Mc Cullough, 2017). However, evidences show that they comprise about $43 \%$ of the agricultural labor force (Doss, 2014) or between 24 and 56\% depending on the country, 
crop, and activity domain as illustrated by Palacios-Lopez et al. (2017). Furthermore, it is claimed that women are less able than men to participate in economic opportunities because they face a work burden that men do not, including the reproductive activities (household activities, caring for children, and elderly household members) (SOFA Team and Doss, 2011).

In any proportion, women largely play a predominant role in food and nutrition, constituting the human link between the field and the plate; according to SOFA Team and Doss (2011). Women produce over 50\% of the world's food and their role is increasing in the rural areas precisely where men are increasingly moving to cities (Banque Mondiale, 2017). In some regions of Africa and Asia, women are involved in rural activity as independent producers, unremunerated family workers, or as agricultural wage workers. Women work not only in the fields and pastures, but also in agricultural processing and packaging plants (Lastarria-Cornhiel, 2006). However, much evidence shows that there is no gender equality in ownership and control over productive resources such as land, livestock, farm machinery, and transport equipment. In addition, women's access to credit, technical, and market information, fertilizer or water is highly restricted (Vepa, 2005; Kinkingninhoun et al., 2008; Agarwal, 2015). These constraints in access to resources limit productivity, as evidenced by the lower yields realized by women. If women were given similar opportunities and access to the productive resources as men do, they are equally productive as male farmers, confirmed Agarwal (2015). The consequence of gender discrimination in access to resources is that total output is lower than it would be if women had greater access to these resources, the wider implication being slower economic development (Khachaturyan and Peterson, 2018).

In their investigation of the factors influencing women's participation as agricultural labor, Palacios-Lopez et al. (2017) found that the availability of household labor, culture-specific gender roles and socio-economic factors were the key criteria. The labor available in the household includes the number, age, and gender composition of children, adult, and elderly in the household, in addition to the availability and accessibility of hired and/or community labor. The norms and culture associated with the gender roles in turn determine the capacity of men and women to allocate labor time across reproductive (household) and productive (economic) activities. As clarified by SOFA Team and Doss (2011) these norms and culture vary over space and time. The household economic status and gender differences for instance in education, may affect the scope of individual labor allocation or off-farm opportunities available to women compared to men. For instance, as rural wage laborer, women receive lower wage than men and their opportunity for education, skill formation and of shifting to better paid work are also narrow (Vepa, 2005). Given the possibility of differential control over the proceeds from cash and food crops by gender, the overall female labor share in agriculture may further depend on the land allocation to different crops over all the area of land cultivated. These differences are deeply again culturally determined (Palacios-Lopez et al., 2017). According to Lastarria-Cornhiel (2006), in sub-Saharan Africa where men control most of the land, women's work in high-value cash crops does not guarantee their control over the generated income. In fact, women's increasing role as economic producers does not necessarily increase their decision-making power in the household and community. Women who work off-farm as wage workers and directly receive their wages have more control over those wages, over how they are allocated, and therefore are more empowered. This is not the case for women who work as unremunerated family workers, except in the womenheaded households. Changes in the structure of the agricultural labor force depend on economic development and material conditions. For instance, while in general, there are signs of gender differentiated labor substitution through machinery, the gender-sensitive labor-saving technologies enable to retain the level of women's labor input into agriculture (Palacios-Lopez et al., 2017). In contrast, household's female labor share may increase when the labor brought in from outside the household (through hiring or labor exchange programs) essentially targets the male activities.

As far as considering agriculture as an entrepreneurial activity, many studies show that women are more risk-averse than men, and this affects their pursuit of specific functional strategies and ultimately their performance (Tomasz, 2001; Boohene et al., 2008; Garba, 2011; Sepulveda and Bonilla, 2014). Women entrepreneurs suffer a lot of set back and constraints in exploiting their potential unlike their men counterpart as a result of socialcultural structures (Garba, 2011). Policy makers should consider the interactions among business performance, owner-manager characteristics, and social structures in formulating policies and programs aimed at alleviating the imbalance between the sexes in access to resources (Boohene et al., 2008). One way of instilling an entrepreneurial mindset is through education and learning which are both critical in developing the entrepreneurial orientation and success (Mwaura et al., 2015). Making rural labor markets function better and providing labor-saving technologies and public goods and services, would enable women to contribute more effectively to, and benefit more fully from, the economic opportunities offered by agricultural growth (SOFA Team and Doss, 2011)

In rice farming, the involvement of women depends on the ecology and culture associated with the crop. As reported by Agboh-Noameshie et al. (2013), for instance in The Gambia, swampland farming including rice is solely a women's duty whereas men cultivate cash crops and their fields are usually larger. In Mali, rice is traditionally grown only by women near rivers and wetlands. Rice is considered a man's crop in some communities, and a woman's crop in others, while in many places, the gender pattern for rice cultivation is complex. Furthermore, the division of labor among men and women shows distinct tasks: seedbed and land preparation, fertilizer spraying, and pesticide application are performed by men and other tasks are shared between men and women, including transplanting, weeding, manual harvesting, and post-harvest activities. The role of women varies: for instance, women in the Philippines clear and maintain the paddy bund (dikes); in Yogyakarta (Java, Indonesia), Myanmar, and the Philippines where manual transplanting is a common practice for crop establishment, it is commonly conducted in groups mostly consisting of women, 
men can be involved and assist with pulling and distributing seedlings (Akter et al., 2017). In Sierra Leone, men carry out land preparation at the beginning of the cropping season and women are in charge of planting, weeding, and harvesting activities. In Cameroon, some activities such as tilling, transplanting, and harvesting are performed by both men and women (AgbohNoameshie et al., 2013). This division of tasks can however be very complex and unbalanced at the expense of women and youth who become the main labor providers.

The significant role of women in rice farming in Burkina Faso, Côte d'Ivoire, Madagascar, and Sierra Leone, the countries of the current study is undeniable. For instance, nearly 55\% of local rice producers in Côte d'Ivoire are women, and in Sierra Leone, nearly $50 \%$ of the agricultural labor force of rural women is invested in rice-based production, the rest being used in vegetable production, or in off-season crops. Gender and social dynamics in rice-based systems need to be understood to design interventions and improve outcomes of development projects/programs. In this regard, the objective of the current study is to analyze the labor inputs in rice-based farming systems within a gender perspective. Three specific research questions are addressed, namely (1) understanding the differences in labor allocation between different activities by men and women with a special focus on rice related activities, (2) assessing how the labor inputs in rice farming are determined by household/farm characteristics, and (3) explaining how the incomes from various sources, and farm characteristics are distributed across the different groups of labor time in rice farming.

\section{METHODOLOGY}

In Burkina Faso, Côte d'Ivoire, Madagascar, and Sierra Leone, the countries where the study was conducted, rice is one of the essential crops in terms of production, area coverage, and consumption. Since 2013, in Burkina Faso, production of milled rice has been estimated on average at about 220,000 tons annually, 1.3 million tons in Côte d'Ivoire, 2.3 million tons in Madagascar, and 700,000 tons in Sierra Leone (United States Department of Agriculture-USDA, 2019). Rice farming in Côte d'Ivoire occupies 800,000 hectares, more than half of the land cultivated with cereals. In Sierra Leone and Madagascar, rice is the staple food, with an annual per capita consumption of $100 \mathrm{Kg}$ and more. Rice provides food and income to farmers, processors, and traders. Despite its increasing importance, local production has remained lower than the domestic needs in the four countries. Based on United States Department of AgricultureUSDA (2019) data, since 2013, domestic production in Burkina Faso, Côte d'Ivoire, Madagascar, and Sierra Leone covers respectively $35,54,87$, and $68 \%$ of consumption needs resulting in importing large quantities of milled rice annually. The promotion of domestic rice production has therefore remained a key element in the countries' strategies to improve food security, stimulate economic growth, and increase rural incomes.

\section{Sampling}

The data were collected at community, household and individual levels from men, women, and youths in five villages in each
TABLE 1 | Sampling of male and female respondents in Burkina Faso, Côte d'Ivoire, Madagascar, and Sierra Leone.

\begin{tabular}{llccc}
\hline Country & Hub & $\begin{array}{c}\text { Male } \\
\text { respondents }\end{array}$ & $\begin{array}{c}\text { Female } \\
\text { respondents }\end{array}$ & Total \\
\hline Burkina Faso & Mangodara & 63 & 57 & 120 \\
Côte d'Ivoire & Gagnoa & 64 & 98 & 162 \\
Madagascar & Ambohibary & 80 & 80 & 160 \\
Sierra Leone & Mangrove & 101 & 99 & 200 \\
\hline Total & & 308 & 334 & 642 \\
\hline
\end{tabular}

country within the established rice sector development hubs ${ }^{1}$. Villages were purposely selected from the 32 villages in the hub in which baseline data were previously collected. The 32 baseline survey villages were composed of 5 categories where specific research activities were on-going ${ }^{2}$ and a category of control villages. To obtain the five investigated villages, one village was purposively selected from the research villages based on the availability of all or most of the rice value chain actors in the village.

Within each village, 15-20 households were randomly selected across the available rice value chain actors. The intrahousehold survey included both the husband and the wife in the interview, making a target of 30-40 respondents per village or 150200 respondents per hub and per country ${ }^{3}$. Table 1 shows the total number male and female respondents interviewed in each country.

Data were collected using survey tools at community and household levels. The individual data include (i) socio-demographic characteristics of respondents, (ii) the activity and income profile, (iii) access, use and control of productive resources, technologies, and income, (iv) women decision making in households, (v) awareness and usage of rice technologies, and (vi) constraints and opportunities related to the roles of men and women in rice farming. The individual questionnaire is added in Supplementary Materials.

\footnotetext{
${ }^{1}$ Rice sector development hubs are geographical zones where rice research products are integrated across the rice value chain to achieve development outcomes and impact. In the Hubs, Africa Rice and national scientists introduce, evaluate and validate new rice technologies, and work with development partners to facilitate the training of farmers, dissemination of those technologies, and establish linkages among actors along the rice value chain (such as rice millers, input dealers, and rice marketers). Since 2012, Africa Rice facilitated the establishment of 70 hubs in 25 countries. Baseline surveys were conducted in 2013-2014.

${ }^{2}$ The research activities include (1) participatory varietal selection, (2) agronomic activities, (3)mechanization, (4) seed production training, and (5) processing and post-harvest.

${ }^{3}$ In Burkina Faso, due to non-availability of household members, less than the target number was interviewed. In Côte d'Ivoire, the surplus number came from interviews with female parboilers in some parboiling business centers. In Madagascar, interest to participate in the survey was manifested in some villages leading to exceeding the target survey sample size.
} 


\section{Analytical Framework Conceptual Framework}

Several frameworks are considered in gender analyses. The current study principally follows Moser's gender framework (Moser, 1989). The framework recognizes that different gender roles condition which activities, tasks, and responsibilities that in the end are perceived as male or female. Accordingly, women have a triple role consisting of reproductive, productive, and community-managing activities whereas men primarily undertake productive and community-politics activities. The aspect of access to resources is drawn from the Harvard analytical framework (Overholt et al., 1985) which analyzes men and women's access, use and control over productive resources, technologies, and income with the aim of demonstrating that there is an economic case for allocating resources to women as well as men.

The productive, reproductive, community-managing, and community-politics roles described by Moser (1989) are defined. Productive roles include work done for pay in cash or kind whether it is through market production with an exchange-value, subsistence/home production with actual use-value or potential exchange-value. Reproductive roles comprise the biological reproduction, the care and maintenance of the current, and future work force. As such defined, reproductive roles go beyond childbearing/rearing responsibilities to also include the domestic tasks done by women, required to guarantee the maintenance and reproduction of the labor force. The community managing roles and community political roles are presented as different activities; the first is regarded as an extension of the reproductive roles, to ensure the provision and maintenance of scarce resources of collective consumption, such as water, health care, and education and the second is about organizing at the formal political level, often within the framework of national politics. While the community management role is mostly voluntary unpaid work, undertaken in "free" time, the community political role is usually paid work, either directly or indirectly, through status or power [International Labor Organization (ILO), 1998].

The most recent classification of the time allocation associated with the World Bank considers four work categories: (1) market work including paid and unpaid work devoted to production of goods sold in the market, commuting to the workplace, and the time spent looking for work; (2) unpaid domestic work including productive activities for which markets could potentially exist, such as cooking, fetching water, cleaning, and care for children; (3) personal care comprising sleep, eating, and drinking, and other personal services such as hygiene, visits to the doctor, etc.; and (4) leisure, social and study activities including hobbies, games, recreation, sports, socializing, and so on. In this study, we adopt the four categories of productive, reproductive, sociocultural, and leisure time allocation. Productive activities are further separated out between rice related activities (production both on farm and in post-harvest management) and parboiling 4 and the other agricultural activities including farming other

\footnotetext{
${ }^{4}$ Parboiling is a process of steaming rice in its husk before milling. This improves grain quality by reducing breakage and retaining nutritional properties (Ndindeng et al., 2015).
}

crops, animal rearing, fishing, hunting, and agricultural products or by products transformation. Furthermore, non-agricultural activities are all productive activities apart from farming. These include handicraft, regular or part-time employment, marketing /trading, etc.

\section{Econometric Analysis}

Determinants of the labor input into rice production were analyzed through a general linear regression formulated as follows:

$$
\begin{aligned}
Y_{i j}= & A r_{i j}+R l_{i j}+I r_{i j}+H l_{i j}+P e q_{i j}+N a g_{i j}+P a r_{i j}+T_{i j} \\
& +F_{i j}+D_{j}+e_{i j}
\end{aligned}
$$

where the dependent variable $Y$ refers to the hours spent in rice production by the farmer $i$ in country $j$, and the independent variables are the total farm area $(A r)$, share of rainfed lowland in relation to the rice farm $(R l)$, share of irrigated rice field in relation to the rice farm $(I r)$, access to hired labor $(H l)$, access to production equipment $(P e q)$, hours spent on nonagricultural activities (Nag), engagement in parboiling activities (Par), interaction terms $(T)$, farmer characteristics $(F)$, country dummies $D$, and an error term $e$.

The regression estimation results are based on differences in outcome variables between populations at the mean (i.e., ordinary least squares regression), or a population average effect (i.e., logistic regression models), after adjustment for other explanatory variables of interest. These are often done assuming that the regression coefficients are constant across the population-in other words, the relationships between the outcomes of interest and the explanatory variables remain the same across different values of the variables.

In the current analysis, the interest is also to deepen the understanding of the percentile group differences across the distribution of a given dependent variable rather than only at the mean (Lê Cook and Manning, 2013). Concretely four groups categories were made based on the percentiles of rice production labor inputs for both men and women and the means of the explanatory variables conditional on rice production labor inputs were computed.

\section{Data Description}

Table 2 shows, at the individual level, the mean values of the variables associated with labor inputs. The intra-household analysis recognizes that there are differences between the male and female farmers in the household, hence these differences [the columns Diff $(\mathrm{M}-\mathrm{W})$ ] are indicated. A positive difference indicates that the mean value for male farmers is higher than for female farmers; a negative value indicates that female farmers have higher mean values than male farmers. Some of the variables would lead to the same values when the household has joint decision such as farm size and income. This may not always be the case; the only variable which is generally be expected to be the same is the number of members in monogamous households.

The summary statistics show that the respondents are in their early forties, male farmers being older than the female farmers. 
TABLE 2 | Descriptive statistics of factors associated with labor inputs in Burkina Faso, Côte d'Ivoire, Madagascar, and Sierra Leone.

\begin{tabular}{|c|c|c|c|c|c|c|c|c|}
\hline & \multicolumn{2}{|c|}{ Burkina Faso } & \multicolumn{2}{|c|}{ Côte d'Ivoire } & \multicolumn{2}{|c|}{ Madagascar } & \multicolumn{2}{|c|}{ Sierra Leone } \\
\hline & (1) & (2) & (3) & (4) & (5) & (6) & (7) & (8) \\
\hline & Mean & Diff (M-W) & Mean & Diff (M-W) & Mean & Diff (M-W) & Mean & Diff (M-W) \\
\hline Age & 44.38 & $11.69^{\star \star \star}$ & 41.59 & $7.93^{\star \star \star}$ & 40.72 & $3.81^{\star}$ & 43.80 & $9.37^{\star \star \star}$ \\
\hline Number of household members & 10.63 & 1.24 & 7.37 & 0.76 & 4.96 & -0.04 & 13.38 & 0.88 \\
\hline Total rice area (ha) & 1.63 & 0.68 & 1.09 & 1.17 & 0.26 & $0.33^{\star}$ & 2.65 & $2.08^{\star \star \star}$ \\
\hline Rice production labor (persons) & 1.66 & 0.19 & 3.08 & $1.13^{\star \star \star}$ & 1.27 & $0.70^{\star \star \star}$ & 2.96 & $1.72^{\star \star \star}$ \\
\hline $\begin{array}{l}\text { Income from rice production (2005 } \\
\text { PPP USD) }\end{array}$ & 983.51 & $787.55^{\star}$ & 593.41 & $591.67^{\star \star}$ & 778.65 & $548.92^{\star \star}$ & 1847.04 & $954.81^{\star}$ \\
\hline Other agricultural labor & 1.68 & 0.31 & 2.74 & $1.35^{\star \star \star}$ & 2.22 & -0.18 & 0.45 & $-0.35^{\star}$ \\
\hline $\begin{array}{l}\text { Other agricultural income (2005 PPP } \\
\text { USD) }\end{array}$ & 1410.24 & $1384.29^{*}$ & 1613.14 & 1925.38 & 1321.28 & $615.13^{\star}$ & 658.47 & -83.18 \\
\hline Non-agricultural labor & 1.34 & $0.90^{\star}$ & 2.37 & 0.26 & 1.17 & $0.91^{\star \star}$ & 1.18 & -0.30 \\
\hline $\begin{array}{l}\text { Non-agricultural income (2005 PPP } \\
\text { USD) }\end{array}$ & 658.23 & 1133.88 & 529.13 & 629.81 & 1449.82 & $1058.95^{\star \star}$ & 1863.68 & 627.74 \\
\hline Total income (2005 PPP USD) & 1734.28 & $1571.71^{\star \star}$ & 1465.51 & $2049.90^{\star}$ & 1633.75 & $1003.05^{\star \star \star}$ & 2131.53 & 444.87 \\
\hline$=1$ if access to irrigation & 0.90 & 0.02 & 0.91 & $0.13^{\star}$ & 0.99 & 0.01 & 0.32 & 0.11 \\
\hline$=1$ if access to fertilizer & 0.96 & -0.05 & 0.94 & 0.03 & 0.99 & 0.03 & 0.86 & 0.04 \\
\hline$=1$ if access to improved seed & 0.89 & 0.06 & 0.95 & 0.05 & 0.94 & -0.04 & 0.74 & 0.03 \\
\hline$=1$ if access to hired labor & 0.85 & -0.09 & 0.97 & $0.06^{*}$ & 0.99 & 0.00 & 0.97 & 0.01 \\
\hline$=1$ if access to production equipment & 0.80 & 0.08 & 0.87 & 0.01 & 0.97 & 0.03 & 0.51 & -0.02 \\
\hline Observations & 120 & 120 & 162 & 162 & 160 & 160 & 200 & 200 \\
\hline
\end{tabular}

${ }^{*} p<0.05,{ }^{* \star} p<0.01$, and ${ }^{* \star *} p<0.001$. Having access to an input is defined as "Access only" or "Have control".

Large households are observed in Sierra Leone and Burkina Faso, with 10 members or more on average in each household, whereas in Madagascar, the households have on average 5 members. The farm size ranges between 1 and 2 ha on average in the three studied countries in West Africa. In Madagascar, farm sizes are small, about a quarter of a hectare. Regarding the rice production labor, 1-3 persons from the household are involved; men, significantly more than women in Côte d'Ivoire, Madagascar, and Sierra Leone.

The annual income from rice varies between close to 6001,800 dollars on average, it is smaller in Côte d'Ivoire and largest in Sierra Leone; men significantly earn higher than the women in rice production activities. Other agricultural labor engages about 1-2 persons, men being significantly more involved in Côte d'Ivoire but less so in Sierra Leone. The other agricultural income is between 600 and 1,600 dollars, highest in Côte d'Ivoire and lowest in Sierra Leone. Almost the same level of nonagricultural labor is observed between 600 and 1,800 dollars, but lowest in Burkina Faso and highest in Sierra Leone. The total income follows similar trends. Not all rice growers engage in nonagricultural activities and were hence treated as missing; implying that the sum of incomes does not necessarily match the mean of total income.

An observation from the labor and level of income is that rice farming and non-agricultural activities are more lucrative in Sierra Leone, whereas in Burkina Faso and Côte d'Ivoire, other agricultural non-rice activities are performing best. In Madagascar, both other agricultural and nonagricultural activities generate almost the same revenues.
Figure 1 illustrates well the differences in labor and incomes across countries.

Generally, in all the countries, male farmers spend more time in rice production than female farmers and very large income differences are noted in the 4 countries. In Sierra Leone, it appears the labor time and income between male and female farmers are almost in the same proportions. However, in Burkina Faso, while male and female farmers spend almost the same time in rice production activities, male farmers' income is more than double the female farmers' income. Rice parboiling is undeniably an activity principally practiced by women. Interesting to note is that in Sierra Leone it is very lucrative for female processors, but the income generated by the involved men is negligible as they are often engaged as hired casual labor. In Côte d'Ivoire where female processors put in long hours of work, they earn lesser than the male processors involved.

Differences are also observed with respect to other agricultural activities and non-agricultural activities. In Burkina Faso and Côte d'Ivoire, male farmers engage more into other on-farm activities (e.g., livestock) and earn noticeably more than female farmers. The reverse is observed for Madagascar where the participation of male farmers in other agricultural activities is lower but more rewarding than for female farmers. The employment of farmers in non-agricultural activities and related income is again higher for male farmers than female farmers. An exception is noted for Sierra Leone, where male farmers, in spite of lesser labor inputs, earn more than female farmers.

Overall, male farmers are more involved in different types of productive activities and earn more income than female farmers, 


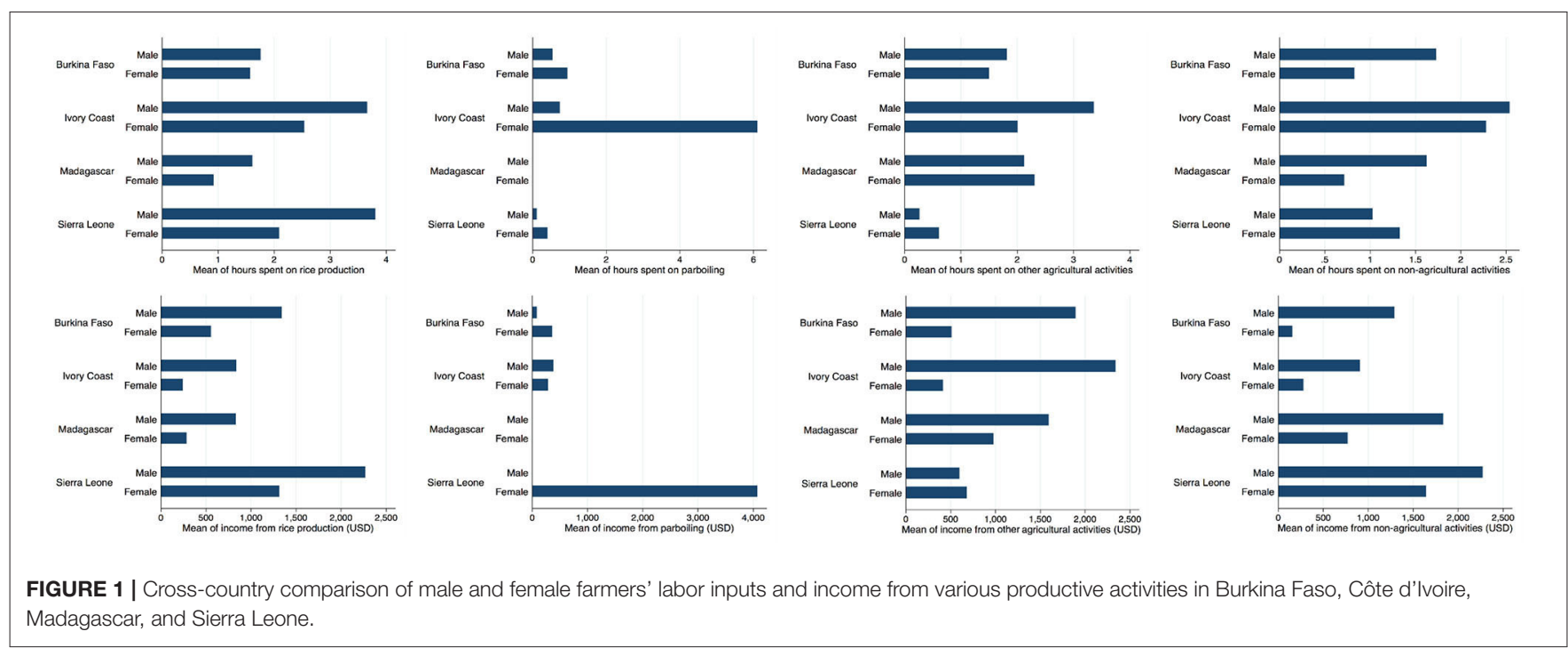

except for a few noted cases and the flagrant activity of parboiling where women are thriving. Differences in nominal income may be associated with exact nature of the other on-farm or off-farm activity and its profitability whereas across countries, they may be due to the value of money.

In terms of access to agricultural inputs, high levels of access are reported, except for irrigation, and production equipment, to a certain extent in Sierra Leone.

\section{RESULTS}

\section{Average Hours Spent in Various Activities}

Table 3 details the time spent in various activities. The sum of the reported time spent in all the activities is close to $24 \mathrm{~h}$ in Côte d'Ivoire, Madagascar, and Sierra Leone (respectively 22.96, 23.3, and $23.36 \mathrm{~h}$ ). However, in Burkina Faso, the sum of the time is $19.5 \mathrm{~h}$, much lower than the hours in a day. The reason is due to the non-engagement in non-agricultural activities which was treated as missing.

The time spent in all the productive activities on average varies between 4 and $6 \mathrm{~h}$ per day, is lowest in Burkina Faso and highest in Côte d'Ivoire. As illustrated in Figure 1, male farmers significantly spend more time in rice production than women in Côte d'Ivoire, Madagascar, and Sierra Leone; in other agricultural activities in Côte d'Ivoire and in non-agricultural activities in Burkina Faso and Madagascar. In Sierra Leone, women spend more time in other agricultural activities than men.

On average, farmers spend between 1 and $3 \mathrm{~h}$ per day in rice farming. This translates into 45-135 working days in a year, indicating that double cropping is actively practiced particularly in irrigated areas. The computation breaks the myth of women's involvement in rice farming, unless one may consider other parameters such as considering the number of men and women involved in specific rice farming activities. Parboiling, that is practiced prominently in West Africa as a women's activity, as it is significantly observed in Côte d'Ivoire and Sierra Leone.
Reproductive activities, taking 3 to close to $4 \mathrm{~h}$ per day, are generally performed by women, confirming their involvement in such work which is mostly unpaid. Sharing of the reproductive responsibilities with men is however noticed for instance in collection of firewood and caring for the sick and elderly members. It is observed that socio-cultural activities engage both men and women; however, men significantly participate more in groups and associations in Madagascar, in religious activities in Côte d'Ivoire and Sierra Leone. Socio-cultural activities occupy close to 1.5-3 h per day while resting and leisure take about 9$14 \mathrm{~h}$ per day. Generally, women significantly spend more time on body care while men are more engaged in religious and political activities and in leisure and social visits.

An assumption exists that when farmers are involved in other activities, this will limit their engagement in rice production. This assumption is tested through correlations among labor inputs on different productive activities and on the time allocation in the reproductive and socio-cultural activities by the rice growers. Results are presented in Table 4.

For male farmers, a negative relationship exists between rice production and parboiling, other agricultural, and nonagricultural activities. This correlation indicates that male farmers tend to specialize in specific productive activities. The time spent in parboiling is positively associated with the reproductive time and negatively correlated with leisure time. Parboiling, being essentially a women's activity and practiced in some countries but not others, to the men who practice it appears to be complementary to the involvement in reproductive activities, while competing for leisure. The negative relationship is also noted between on the one hand other agricultural activities, non-agricultural activities, reproductive activities, and social activities and leisure on the other hand. For female farmers, a negative relationship also exists between rice production on the one hand and parboiling and leisure on the other hand. Parboiling has a positive relationship with other agricultural activities but is negatively correlated with leisure. 
TABLE 3 | Time allocation in Burkina Faso, Côte d'Ivoire, Madagascar, and Sierra Leone.

\begin{tabular}{|c|c|c|c|c|c|c|c|c|}
\hline & \multicolumn{2}{|c|}{ Burkina Faso } & \multicolumn{2}{|c|}{ Côte d'Ivoire } & \multicolumn{2}{|c|}{ Madagascar } & \multicolumn{2}{|c|}{ Sierra Leone } \\
\hline & (1) & (2) & (3) & (4) & (5) & (6) & (7) & (8) \\
\hline & Mean hours & Diff (M-W) & Mean hours & Diff (M-W) & Mean hours & Diff (M-W) & Mean hours & Diff (M-W) \\
\hline \multicolumn{9}{|l|}{ Productive activities } \\
\hline Rice production & 1.66 & 0.19 & 3.08 & $1.13^{\star \star \star}$ & 1.27 & $0.70^{\star \star \star}$ & 2.96 & $1.72^{\star \star \star}$ \\
\hline Parboiling & 0.83 & -0.41 & 5.25 & $-5.36^{\star \star}$ & & & 0.27 & $-0.29^{\star \star \star}$ \\
\hline Other agricultural activities & 1.68 & 0.31 & 2.74 & $1.35^{\star \star \star}$ & 2.22 & -0.18 & 0.45 & $-0.35^{\star}$ \\
\hline Non-agricultural activities & 1.34 & $0.90^{\star}$ & 2.37 & 0.26 & 1.17 & $0.91^{\star *}$ & 1.18 & -0.30 \\
\hline Total hours on productive activities & 3.61 & 0.42 & 6.11 & $2.14^{\star \star \star}$ & 4.66 & $1.42^{\star \star \star}$ & 4.34 & $0.69^{*}$ \\
\hline \multicolumn{9}{|l|}{ Reproductive activities } \\
\hline Kitchen activities & 1.73 & -0.40 & 1.65 & $-0.93^{\star}$ & 1.09 & $-1.44^{\star \star \star}$ & 0.94 & $-1.42^{\star * \star}$ \\
\hline Washing of clothes & 1.08 & 0.45 & 0.90 & -0.14 & 0.49 & $-0.77^{\star \star \star}$ & 0.56 & $-0.77^{\star \star \star}$ \\
\hline House cleaning & 0.39 & -0.07 & 0.69 & 0.01 & 0.40 & $-0.55^{\star \star \star}$ & 0.54 & $-0.42^{\star \star \star}$ \\
\hline Firewood collection & 1.05 & -0.18 & 0.83 & 0.09 & 0.42 & $0.38^{\star \star \star}$ & 0.61 & -0.06 \\
\hline Water fetching & 0.70 & 0.05 & 0.71 & -0.02 & 0.19 & -0.08 & 0.29 & $-0.45^{\star \star \star}$ \\
\hline Childcare & 1.11 & 0.16 & 0.82 & -0.17 & 0.49 & $-0.67^{\star \star \star}$ & 0.92 & $-0.64^{\star \star \star}$ \\
\hline Caring the old/sick & 0.89 & $0.40^{\star *}$ & 0.87 & $0.37^{\star \star}$ & 0.16 & -0.04 & 0.28 & 0.15 \\
\hline Total hours on reproductive activities & 3.85 & $-1.92^{\star \star \star}$ & 3.91 & $-2.99^{\star \star \star}$ & 3.24 & $-3.17^{\star \star \star}$ & 3.46 & $-3.53^{\star \star \star}$ \\
\hline Socio-cultural activities & & & & $A$ & & & & \\
\hline Group/association & 0.79 & -0.10 & 0.78 & 0.10 & 0.10 & $0.11^{*}$ & 0.39 & -0.01 \\
\hline Religious activities & 0.92 & 0.07 & 1.00 & $0.23^{*}$ & 0.67 & 0.01 & 1.00 & $0.34^{\star \star \star}$ \\
\hline Political activities & 0.75 & -0.23 & 0.95 & 0.12 & 0.01 & -0.01 & 0.29 & 0.18 \\
\hline Burials, weddings, etc. & 0.88 & 0.26 & 1.04 & 0.15 & 0.56 & 0.00 & 0.85 & 0.21 \\
\hline Total hours on socio-cultural activities & 2.57 & 0.20 & 2.93 & $0.59^{*}$ & 1.35 & 0.11 & 2.33 & $0.67^{\star \star \star}$ \\
\hline \multicolumn{9}{|l|}{ Resting/leisure } \\
\hline Body care & 0.77 & 0.09 & 0.87 & -0.04 & 0.73 & $-0.18^{\star \star}$ & 1.03 & 0.10 \\
\hline Social visits & 1.78 & 0.39 & 1.22 & -0.13 & 0.49 & 0.08 & 1.54 & $0.85^{\star \star \star}$ \\
\hline Sleep & 5.61 & 0.38 & 7.04 & -0.29 & 9.65 & 0.44 & 8.13 & 0.03 \\
\hline Leisure & 2.12 & $0.70^{*}$ & 1.50 & $0.31^{*}$ & 3.18 & $0.88^{\star \star \star}$ & 2.53 & $0.67^{\star \star}$ \\
\hline Total hours on resting/leisure & 9.72 & 1.26 & 10.01 & 0.05 & 14.05 & $1.23^{\star \star \star}$ & 13.23 & $1.71^{\star \star \star}$ \\
\hline Observations & 120 & 120 & 162 & 162 & 160 & 160 & 200 & 200 \\
\hline
\end{tabular}

${ }^{*} p<0.05,{ }^{* *} p<0.01$, and ${ }^{* * *} p<0.001$. Bold values refer to the sum of hours spent on different tasks within categories of activities. Parboiling is not done in Madagascar.

Other notable negative correlations are between reproductive and non-agricultural activities, and between leisure time and reproductive activities, and social activities. This indicates that rice production and parboiling activities compete for labor. It appears that leisure is always traded-off.

\section{Determinants of Labor Input in Rice Production}

Table 5 shows the determinants of labor input disaggregated by gender considering different explanatory variables. Model (1) shows the influence of the total area, the share of rainfed lowland and share of irrigated rice field, access to production resources, and the consideration that rice farmers, male, and female, are involved in other productive activities as well. In reference to the econometric Equation (1), the coefficients of interaction terms $(T)$ and farmer characteristics $(F)$ are excluded. Access to production equipment is significant and positive, indicating that mechanization has not yet induced substitution of labor. Interestingly, the engagement in non-agricultural activities and in parboiling activities has a negative effect on labor time in rice production for men. This supports the noted specialization in productive activities. The latter case on parboiling is not observed for women.

Model (2) and Model (3), in an effort to fully inform the labor time in rice production within the realistic context of farming households and access to production resources, consider the production environment and farmers' characteristics. The full Model (3) additionally includes the interaction terms as explanatory variables. In model (2), the labor time in rice production increases with better access to production equipment by the male or female farmers, and if the female farmers have completed the university level of education. Time in rice production significantly declines, when the male and female farmers contribute more time to non-agricultural activities, and if the male farmer is also engaged in parboiling and has attained university education. In model (3), the time in rice farming significantly declines with access to production equipment in irrigated rice fields 
TABLE 4 | Correlation among labor inputs for rice farmers in Burkina Faso, Côte d'Ivoire, Madagascar, and Sierra Leone.

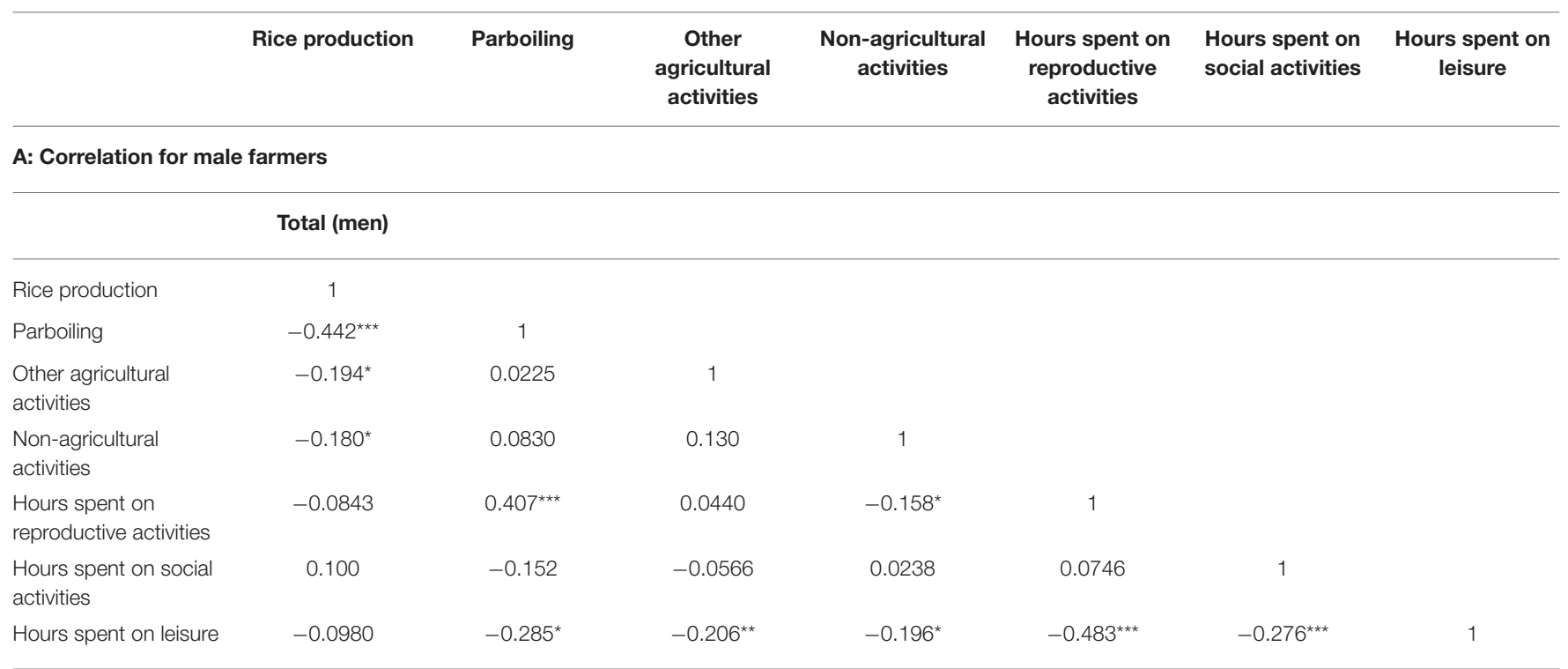

B: Correlation for female farmers

\section{Total (women)}

\begin{tabular}{|c|c|c|c|c|c|c|c|}
\hline Rice production & 1 & & & & & & \\
\hline $\begin{array}{l}\text { Other agricultural } \\
\text { activities }\end{array}$ & -0.0680 & $0.523^{\star \star \star}$ & 1 & & & & \\
\hline $\begin{array}{l}\text { Non-agricultural } \\
\text { activities }\end{array}$ & 0.0129 & -0.0995 & 0.0547 & 1 & & & \\
\hline $\begin{array}{l}\text { Hours spent on } \\
\text { reproductive activities }\end{array}$ & 0.0469 & -0.0866 & -0.125 & $-0.267^{\star \star}$ & 1 & & \\
\hline Hours spent on leisure & $-0.164^{\star}$ & $-0.363^{\star \star \star}$ & -0.172 & -0.0756 & $-0.163^{*}$ & $-0.217^{\star \star}$ & 1 \\
\hline
\end{tabular}

${ }^{*} p<0.05,{ }^{* *} p<0.01$, and ${ }^{* \star *} p<0.001$.

and the above results are maintained for engagement in non-agricultural activities and in rice parboiling, even for female farmers.

Female farmers who have access to production equipment and have done university education allocate more labor time in rice farming. Across the three models, country dummies confirm significant higher labor time in Côte d'Ivoire and Sierra Leone in comparison to Burkina Faso and a relatively lower labor time in Madagascar.

\section{Factors Associated With Labor Time Across Labor Percentiles}

In Table 6, we expand our exploration of income, other household and farm characteristics conditional on rice production labor inputs for male and female farmers across the percentile groups. Table 7 shows the $t$-test determining if there is a significant difference between the means of different percentile groups in relation to overall sample mean for the different variables.

Across the countries, the average labor time used in rice production is $2.8 \mathrm{~h}$ per day for male farmers. The median is $3 \mathrm{~h}$ per day, and the 25 and 75th percentiles are 1.7 and $4 \mathrm{~h}$ per day respectively. This heterogeneous labor time increases with the household size, implying that not all the household members are directly employed in rice production activities. It also increases with the total area and rice production labor from 1 to 5 persons depending on the percentile group. This can be linked to the need for the farmer's presence to work and supervise laborers. The distribution of income from rice production shows that the largest amounts are obtained by farmers with the labor time in the 2 nd and 3rd percentile groups, but it drops in the last group. Two reasons may be advanced here, notably that there is overemployment, hence the fall in rice income or that the rice income is not fully 
TABLE 5 | Regression results disaggregated by gender in Burkina Faso, Côte d'Ivoire, Madagascar, and Sierra Leone.

Dependent variable: Hours spent on rice production

\begin{tabular}{|c|c|c|}
\hline & \\
\hline & Male farmers & Female farm \\
\hline \multirow[t]{2}{*}{ Total area (ha) } & -0.0551 & -0.0864 \\
\hline & $(0.0582)$ & $(0.0564)$ \\
\hline \multirow[t]{2}{*}{ Share of rainfed lowland (\%) } & 0.0000654 & 0.00223 \\
\hline & $(0.00228)$ & $(0.00160)$ \\
\hline \multirow[t]{2}{*}{ Share of irrigated rice field (\%) } & -0.000763 & -0.00154 \\
\hline & $(0.00238)$ & $(0.00183)$ \\
\hline \multirow[t]{2}{*}{ Access to hired labor } & 0.219 & -0.428 \\
\hline & $(0.483)$ & $(0.389)$ \\
\hline \multirow[t]{2}{*}{ Access to production equipment } & $1.231^{\star \star}$ & $0.598^{\star \star}$ \\
\hline & $(0.396)$ & $(0.190)$ \\
\hline \multicolumn{3}{|l|}{$\begin{array}{l}\text { Access to hired labor }=1 \# \\
\text { Share of rainfed lowland (\%) }\end{array}$} \\
\hline \multicolumn{3}{|l|}{$\begin{array}{l}\text { Access to production equipment } \\
=1 \text { \# Share of rainfed lowland } \\
(\%)\end{array}$} \\
\hline \multicolumn{3}{|l|}{$\begin{array}{l}\text { Access to hired labor }=1 \# \\
\text { Share of irrigated rice field }(\%)\end{array}$} \\
\hline \multicolumn{3}{|l|}{$\begin{array}{l}\text { Access to production equipment } \\
=1 \text { \# Share of irrigated rice field } \\
(\%)\end{array}$} \\
\hline \multirow[t]{2}{*}{ Non-agricultural activities } & $-0.198^{\star \star \star}$ & $-0.102^{\star}$ \\
\hline & $(0.0350)$ & $(0.0472)$ \\
\hline \multirow[t]{2}{*}{$=1$ if engage in parboiling } & $-2.446^{\star \star \star}$ & -0.253 \\
\hline & $(0.464)$ & $(0.184)$ \\
\hline
\end{tabular}

Age

Number of household members

$=1$ if member of an association

$=1$ if received any training

$=1$ if received any extension

service

Education level

Literate in local language

Primary

Junior high school

Senior high school

University

Country dummy (Ref.: Burkina

Faso)

Côte d'Ivoire

Model (1)

$1.964^{\text {** }}$
Model (2)

Male farmers $\quad$ Female farmers

-0.0133
$(0.0599)$
-0.000593
$(0.00252)$
-0.000290
$(0.00270)$
0.0878
$(0.528)$
$1.245^{\star \star}$
$(0.415)$

(0.415)

$-0.202^{\star \star \star}$

(0.0360)

$-2.468^{\star \star \star}$

(0.498)

$-0.000422$

(0.00751)

$-0.0154$

(0.0105)

0.0797

(0.190)

$-0.0250$

(0.194)

$-0.308$

(0.226)

0.147

(0.418)

0.272

(0.363)

0.290

(0.279)

$-0.0889$

(0.245)

$-0.915^{+}$

(0.481)

(0.331) $1.280^{\star \star \star}$

(0.287) $1.910^{\star \star \star}$

(0.364)
Model (3)

\begin{tabular}{cc}
\hline $\begin{array}{c}\text { Male } \\
\text { farmers }\end{array}$ & $\begin{array}{c}\text { Female } \\
\text { farmers }\end{array}$ \\
-0.0801 & -0.0771 \\
$(0.0699)$ & $(0.0583)$ \\
-0.00127 & 0.00517 \\
$(0.00891)$ & $(0.00997)$ \\
0.0166 & $0.0196^{\star \star}$ \\
$(0.0170)$ & $(0.006)$ \\
0.269 & -0.432 \\
$(0.380)$ & $(0.998)$ \\
1.054 & $0.935^{\star}$ \\
$(0.654)$ & $(0.450)$ \\
-0.003 & -0.001 \\
$(0.008)$ & $(0.011)$ \\
0.005 & -0.004 \\
$(0.007)$ & $(0.005)$ \\
0.00816 & \\
$(0.006)$ & $0()$. \\
$-0.026^{+}$ & $-0.022^{\star \star \star}$ \\
$(0.014)$ & $(0.006)$ \\
\end{tabular}

$-0.211^{\star \star *}$

$-0.139^{\text {** }}$

(0.0371) (0.0517)

$-2.653^{\star \star \star} \quad-0.325^{+}$

(0.524) (0.194)

$0.000852 \quad 0.00375$

(0.00700) (0.00559)

$-0.0138 \quad-0.00798$

(0.0113) (0.0103)

$0.111 \quad 0.0381$

(0.187) (0.158)

$0.0476-0.161$

(0.183) (0.204)

$\begin{array}{ll}-0.292 & 0.0279\end{array}$

(0.216) (0.206)

$0.0642 \quad 0.214$

(0.433) (0.459)

$0.297 \quad 0.0211$

(0.359) (0.344)

$0.333 \quad 0.0548$

(0.277) (0.230)

$-0.0404 \quad 0.0481$

(0.243) (0.273)

$-0.846 \quad 1.669^{\star \star \star}$

$(0.531) \quad(0.280)$

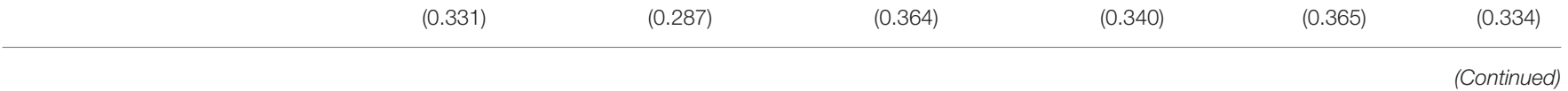


TABLE 5 | Continued

\begin{tabular}{|c|c|c|c|c|c|c|}
\hline \multirow{2}{*}{$\begin{array}{l}\text { Dependent variable: Hours } \\
\text { spent on rice production }\end{array}$} & \multicolumn{2}{|c|}{ Model (1) } & \multicolumn{2}{|c|}{ Model (2) } & \multicolumn{2}{|c|}{ Model (3) } \\
\hline & Male farmers & Female farmers & Male farmers & Female farmers & $\begin{array}{c}\text { Male } \\
\text { farmers }\end{array}$ & $\begin{array}{l}\text { Female } \\
\text { farmers }\end{array}$ \\
\hline \multirow[t]{2}{*}{ Madagascar } & $-0.355^{+}$ & $-0.818^{\star \star \star}$ & $-0.525^{+}$ & $-0.934^{\star *}$ & $-0.561^{*}$ & $-0.925^{\star \star}$ \\
\hline & $(0.210)$ & $(0.191)$ & $(0.279)$ & $(0.294)$ & $(0.284)$ & $(0.295)$ \\
\hline Sierra Leone & $2.881^{\star \star \star}$ & $0.695^{\star \star \star}$ & $2.899^{\star \star \star}$ & $0.749^{\star \star \star}$ & $3.216^{\star \star \star}$ & $0.799^{\star \star \star}$ \\
\hline \multirow[t]{2}{*}{ Constant } & 0.901 & $1.634^{\star \star \star}$ & $1.211^{+}$ & $1.628^{\star \star \star}$ & 1.144 & 1.340 \\
\hline & $(0.612)$ & (0.378) & $(0.637)$ & $(0.447)$ & $(0.708)$ & (0.946) \\
\hline Adjusted $R^{2}$ & 0.488 & 0.390 & 0.488 & 0.388 & 0.503 & 0.388 \\
\hline Observations & 235 & 236 & 234 & 230 & 234 & 230 \\
\hline
\end{tabular}

Standard errors in parentheses. ${ }^{+} p<0.10,{ }^{*} p<0.05,{ }^{* *} p<0.01$, and ${ }^{* \star *} p<0.001$.

TABLE 6 | Summary statistics conditional on labor inputs for rice production in Burkina Faso, Côte d'Ivoire, Madagascar, and Sierra Leone.

\begin{tabular}{|c|c|c|c|c|c|c|c|c|}
\hline & \multicolumn{4}{|c|}{ Male farmers } & \multicolumn{4}{|c|}{ Female farmers } \\
\hline $\begin{array}{l}\text { Number of household } \\
\text { members }\end{array}$ & 7.62 & 8.64 & 11.68 & 10.59 & 6.97 & 8.63 & 11.69 & 8.12 \\
\hline $\begin{array}{l}\text { Income from rice production } \\
\text { (2005 PPP dollar) }\end{array}$ & 1043.91 & 1658.62 & 1655.48 & 1419.43 & 1871.92 & 812.42 & 634.40 & 481.79 \\
\hline Other agricultural labor & 1.69 & 2.11 & 1.79 & 1.44 & 2.04 & 1.49 & 1.36 & 1.32 \\
\hline $\begin{array}{l}\text { Other agricultural income } \\
\text { (2005 PPP dollar) }\end{array}$ & 1706.87 & 1727.44 & 1106.55 & 2954.84 & 1091.59 & 580.81 & 462.42 & 532.34 \\
\hline Non-agricultural labor & 2.39 & 1.21 & 1.28 & 1.09 & 1.38 & 0.88 & 1.12 & 1.59 \\
\hline$=1$ if access to irrigation & 0.93 & 0.98 & 0.92 & 0.85 & 0.96 & 0.88 & 0.88 & 0.76 \\
\hline$=1$ if access to fertilizer & 0.99 & 0.97 & 0.95 & 0.87 & 0.92 & 0.95 & 0.94 & 0.89 \\
\hline $\begin{array}{l}=1 \text { if access to improved } \\
\text { seed }\end{array}$ & 0.96 & 0.80 & 0.88 & 0.87 & 0.76 & 0.94 & 0.85 & 0.87 \\
\hline$=1$ if access to hired labor & 0.91 & 0.98 & 0.98 & 0.94 & 0.99 & 0.92 & 0.99 & 0.93 \\
\hline $\begin{array}{l}=1 \text { if access to production } \\
\text { equipment }\end{array}$ & 0.87 & 0.82 & 0.75 & 0.65 & 0.71 & 0.79 & 0.73 & 0.78 \\
\hline Observations & 72 & 67 & 75 & 94 & 74 & 70 & 78 & 112 \\
\hline $\begin{array}{l}\text { Mean of rice production } \\
\text { labor input }\end{array}$ & \multicolumn{4}{|c|}{2.81} & \multicolumn{4}{|c|}{1.77} \\
\hline 25th percentile & \multicolumn{4}{|c|}{1.66} & \multicolumn{4}{|c|}{0.94} \\
\hline
\end{tabular}

Below 25th percentile (B/W p25), 25th percentile and 50th percentile (B/W p25 and p50), Between 50th percentile and 75th percentile (B/w p50 and p75), and Above 75th percentile (Above p75).

reported by the group, such as the non-traded proportion of the rice produce.

The non-rice agricultural labor is highest in the 2 nd percentile group and drops sharply in the 4 th percentile group and the non-agricultural labor declines across the percentile groups. This description agrees with the negative correlation between rice production and other productive activities, confirming that a certain specialization into rice production may indeed exist. 
TABLE 7 | $t$-test of variables conditional on labor inputs of rice production in Burkina Faso, Côte d'Ivoire, Madagascar, and Sierra Leone.

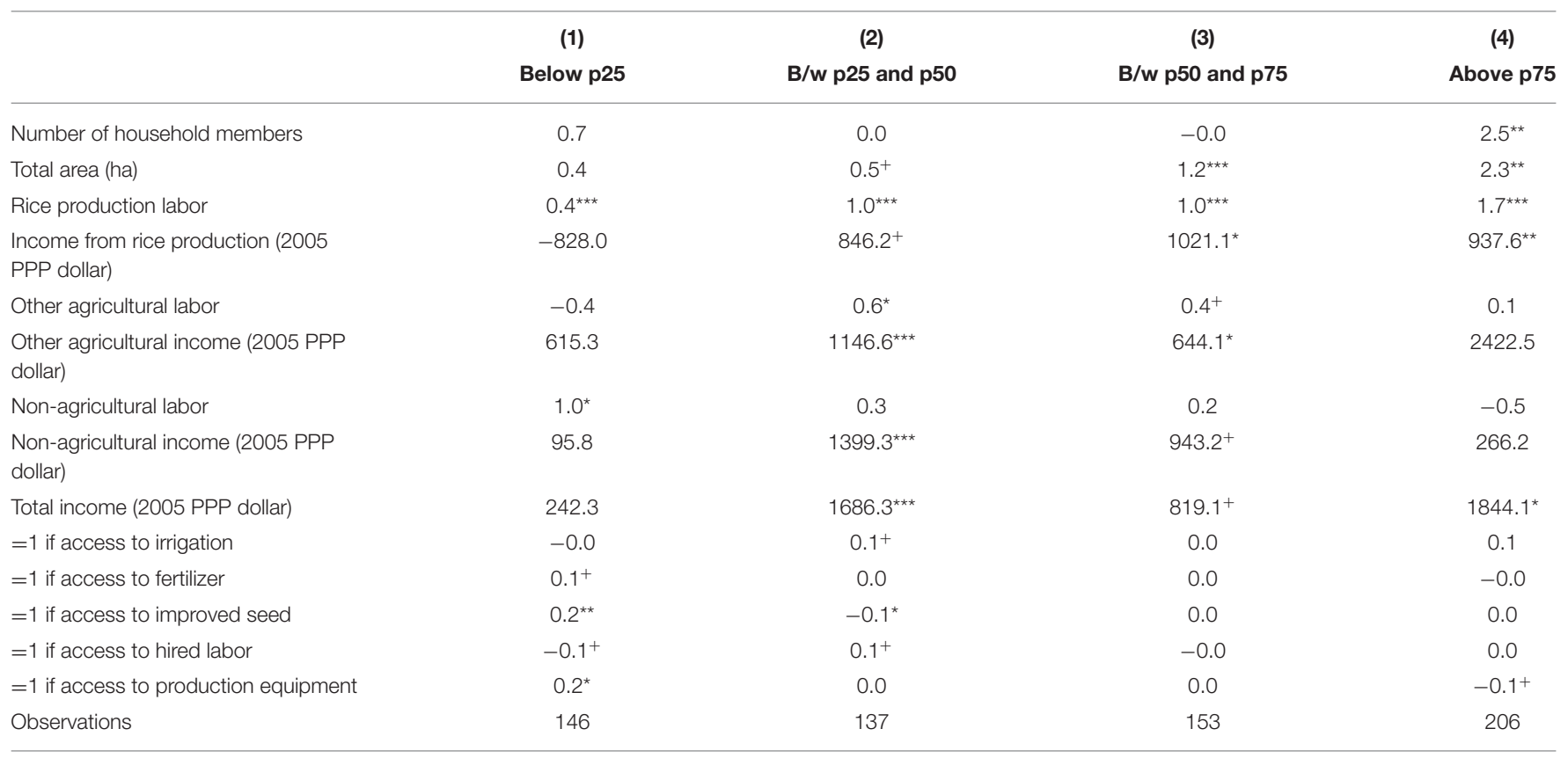

${ }^{+} p<0.10,{ }^{*} p<0.05,{ }^{* *} p<0.01$, and ${ }^{* \star} p<0.001$.

Interestingly, looking at the other agricultural income, one notices that it is highest with the 4 th percentile, an indication that the other agricultural activities may be highly rewarding while requiring less labor. Such activities include growing other crops, livestock rearing, fisheries, and hunting. Access to production resources shows that the male farmers in the 4th percentile group have the least access to irrigation, fertilizer, and production equipment. This indeed explains the largest rice production labor input and lowest labor returns.

The average labor time used in rice production is $1.8 \mathrm{~h}$ per day for female farmers generally across countries. The median is $2 \mathrm{~h}$ per day and the 25 and 75th percentiles are 0.9 and $2.5 \mathrm{~h}$ per day respectively. The labor time increases with the average size of the household, implying that not all the household members are directly employed in rice production activities, because more labor input is required from the respondent. However, it declines in the last percentile justifying the higher labor time, in consideration with the rice farm area and the need to supervise laborers. Looking at the access to production factors, the different percentile groups have almost the same access to resources. In terms of labor and income over different productive activities, in rice production, there appears to be some overemployment and/or partial reporting of income as there are no other plausible explanations to the decline in income over the different labor input percentiles. Labor engaged into other agricultural activities declines with more involvement in rice production. Unlike the general trend of complementarity, here the distribution shows that some labor substitution exists or that some other categories of time requirements are sacrificed. The related income declines too, almost in the same trend. Non-agricultural activities attract female farmers in all the categories. Interestingly, it appears that the lines of engagement by the 1st percentile are the most rewarding in terms of income generation.

\section{DISCUSSION}

The overall time allocation confirms the continued tradition of reproductive care carried out by women, which is undeniably vital for the well-being of the household and the community. As indicated by various authors, domestic responsibilities, such as childcare and caring for the sick, water and firewood collection, and cooking, are usually in the female domain; the cultural norms remain strong, dictating the role of the woman into reproductive responsibilities while excluding the man. For instance, Padmaja et al. (2019) found that in the semi-arid India, compared to men, women spend more time on pre-cooking activities (e.g., fetching firewood and drinking water and in food preparation), cooking, other domestic chores and family care whereas men spend more time on farming, non-farm and livestock activities as well as traveling, commuting, and other miscellaneous activities. Women also participate in farm activities, but differences in time allocation can be observed depending on age, education, and social group. For instance younger women, especially those in the early years of child bearing (18-29 years), use more of their time on domestic, family care, and personal care activities compared to women from 40 years old and above, who spend more of their time on economic activities including farm and non-farm work. As educational level increases, both women and men spend less time on the farm and related activities and more time on domestic, leisure, and other activities. The same general observations were made in Nepal, Bangladesh, and Ghana by Komatsu et al. (2018), were poor women were found to face heavier workloads. Even in the case where women 
were not at home, for instance when they increased their time in other agricultural activities (e.g., wage work and cash cropping), their traditional responsibilities within the home were not assumed by men, but by their daughters (Lastarria-Cornhiel, 2006).

Certain tasks can be combined with other agricultural activities and non-agricultural work close to the homestead, but this is not possible in case of distant off-farm employment (Blackden and Morris-Hughes, 1993; Palacios-López and López, 2015). The observed negative correlations between different productive activities indicate that complementarity in labor allocation may not be working in the study area, for rice farming, distance could be the factor. Furthermore, the negative correlation observed between the time spent on reproductive activities and non-agricultural activities and subsequently with leisure is an indication that sacrifices and trade-offs are made if the female farmer has to do some work outside her home. SOFA Team and Doss (2011) advocated for addressing the constraints associated with the time-consuming and binding reproductive work to enable women to spend their time in more rewarding and more productive ways. It is important to recognize that the value of such reproductive tasks which are not generally rewarded as preconized by Keng Kuek Ser (2016).

Back to the productive activities, the evidence indicates that overall, male farmers are more involved into such activities, in rice, other agricultural or non-agricultural activities. It is only in rice parboiling where women dominate. Such finding cautions the myth of the majority of agricultural laborers being female farmers, at least in rice farming within the studied countries. This claim may be linked to the number of persons on the farm depending on the farming activity, whereas the effective time on the farm is higher for male farmers than for female farmers. There are indeed cases for instance as reported by Enete et al. (2002) where the relative number of households where female farmers provided more field labor was higher among femaleheaded households than among male-headed ones, such as in the case of migration of men.

For rice farming in particular, male farmers tend to specialize, while limiting their involvement into other/non-agricultural activities. In considering parboiling, there appears to be a case of labor inputs competition indicating that rice growers and parboilers cannot combine the two activities. For the case of male farmers, engagement into rice parboiling appears to be closely associated with reproductive tasks, whereas for women, there appears to be distinct groups of rice growers and parboilers. Interesting is that parboiling can be combined with agricultural activities. To be more engaged in any activity, male farmers tend to trade-off their leisure time as previously noted for female farmers.

It is also noted that male farmers earn higher income than female farmers in the different productive activities, except for rice parboiling. This finding indicates that increasing labor input for rice would not immediately result in higher income for female farmers. Female farmers might find better options within other agricultural activities such as food processing and other activities which however can be implemented without constraining their time to fulfill their reproductive duties.
Reducing the overall working time can contribute to reclaiming the time for resting and leisure. This can be achieved through mechanization. A simple indicator of access to production equipment has shown that a good proportion of farmers have access to equipment, namely $80 \%$ and above except in Sierra Leone where it is lowest. At the same time, looking at the percentile groups, it appears that the group that contributes most labor (4th percentile for male farmers) has quite good access to production equipment (65\%). This finding implies that mechanization has not yet reached an adequate substitution level, or that the mechanization is still at the early stage of development. In other developing countries like Bangladesh, allocation of time per day showed that the time spent by a woman in crop production activities (particularly rice) has decreased between 1988 and 2008, due to the fact that many of the post-harvest operations in which female farmers were traditionally involved are now partially done mechanically (i.e., winnowing, parboiling, drying, milling, etc.) (Jaim and Hossain, 2011). Apart from parboiling, the current study has not detailed the specific onfarm activities performed by male and female, to link these to the labor and mechanization requirement. Based on existing gender analyses confirming that female farmers continue to perform activities including clearing of fields, transplanting, sowing, the majority of weed control, harvesting, cleaning of grain, and processing (SOFA Team and Doss, 2011; Kinkingninhoun et al., 2018), it appears that indeed in Africa, mechanization of these activities is limited (see for instance Mujawamariya and Kalema, 2017), calling for an in-depth investigation of the context and the type of mechanization that offers an effective opportunity to engage in rewarding activities without necessarily affecting the farmers' well-deserved leisure time. The observations on the engagement of women are valid for other crops as well. For instance in the cassava production, Enete et al. (2002) found that the number of fields in which women provided more labor for each farm task increased consistently from the initial farm operations, such as land clearing and seedbed preparation, through sowing (planting) and weeding to the final farm operations such as harvesting and transportation. The reverse was the case for men.

In the current study, women's labor input has been found to decline with the usage of production equipment in the irrigated rice fields. Numerous studies have found that women are less likely than men to access both large- and small-scale irrigation infrastructure and technologies. In large-scale farmerled irrigation schemes, women's implicit and explicit exclusion from scheme management decisions and irrigated land allocation limit their access to water (Zwarteveen, 1997; Meinzen-Dick and Zwarteveen, 1998; van Koppen, 1998; Kinkingninhoun et al., 2008). In irrigated conditions, it is indeed a good confirmation that production equipment reduces the labor input, whereas overemployment is not rewarding.

All said, it appears relevant to continue deepening the investigation of the women's labor into rice farming not just for the purpose of determining their labor allocation and input, but importantly in addressing their needs and constraints so that they can optimize their productivity, for the well-being of their households and communities. Continued cut on leisure 
time for all farmers may not be sustainable and healthy in the long run. Hence, it is necessary to create more rewarding opportunities both in agricultural and non-agricultural activities plus recognizing the value of reproductive work and if possible, rewarding it. The finding that even the highly educated female farmers are involved in rice production may be indicative that such good income opportunities exist. These opportunities will allow the flow of labor through removing normative barriers (e.g., the efforts of attracting youth in agriculture), improving access to technical knowledge, technologies, and capital.

\section{CONCLUSION}

This study provides the first evidence that female farmers do not necessarily spend more time than men in rice cultivation in Africa, as it is often assumed. While both male and female farmers are engaged in rice production in our study sites, male farmers tend to specialize in rice production and their labor time is higher than female farmers. Female farmers also specialize and take opportunities in other economic activities such as parboiling and work much more on reproductive activities than male farmers. A trade-off exists between leisure and other activities for farmers. Male farmers generally earn higher income in the different productive activities than female farmers except for rice parboiling. Increasing labor input for rice production did not result in higher income for those farmers.

These results suggest that while rice research community often focuses on reducing labor inputs for rice cultivation by female and increasing female labor productivity through introduction of mechanization or its service provision business [Rice AgriFood System CRP (RICE), 2016], such an approach has limitation and misses the whole context of household labor allocation. We need to consider a holistic approach for enhancing entire labor productivity by female (income per labor time) in the context of the broad farming system. Agricultural research should deal with different options including parboiling and other agricultural activities for better income and improved labor productivity rather than focus on a single commodity, whereas other sectors can also contribute to saving labor time for reproductive activities in which women spent more time than men. Although cultural

\section{REFERENCES}

Agarwal, B. (2015). "Chapter 11: Food security, productivity, and gender inequality," in The Oxford Handbook of Food, Politics and Society, ed Ronald J. Herring (New York, NY: Oxford University Press), 273-300.

Agboh-Noameshie, A., Kabore, A., and Misiko, M. (2013). "Integrating gender considerations in rice research for development in Africa," in Realizing Africa's Rice Promise, eds, M. C. S. Wopereis, D. E. Johnson, N. Ahmadi, E. Tollens, and A. Jalloh, 343-354. Available online at: http://www.africarice.org/ publications/rice_promise/Chap28\%209781845938123.pdf (accessed July 02, 2019). doi: 10.1079/9781845938123.0343

Akter, S., Rutsaert, P., Luis, J., Htwe, N. M., San, S. S., Raharjo, B., et al. (2017). Women's empowerment and gender equity in agriculture: a different perspective from Southeast Asia. Food Policy 69, 270-279. doi: 10.1016/j.foodpol.2017.05.003 norms remain very strong for reproductive activities in Sub Saharan Africa (SSA), gender inequality in reproductive activities should be reduced through sharing those tasks within households or outsourcing to service providers. This could help female farmers having more time for leisure and productive activities.

\section{DATA AVAILABILITY STATEMENT}

The datasets generated for this study are available on request to the corresponding author.

\section{AUTHOR CONTRIBUTIONS}

FK was instrumental in designing the study, collecting data, and preliminary analysis. SK carried out the in-depth analysis. GM contributed in the study design and analysis. She extensively worked on the paper writing. KS analytically contributed to the study and analysis. All authors contributed to making the paper.

\section{FUNDING}

This work was supported by the African Development Bank through the SARD-SC (Support to Agricultural Research for Development of Strategic Crops in Africa) project (PROJECT ID No. P-Z1-AAZ-010, Grant No. 2100155022217) and the Research program on Rice, Rice Agri-Food System CRP (RICE), CGIAR.

\section{ACKNOWLEDGMENTS}

We would like to thank our National Agricultural Research Systems partners. Invaluable comments and suggestions on this paper from the journal reviewers are gratefully acknowledged.

\section{SUPPLEMENTARY MATERIAL}

The Supplementary Material for this article can be found online at: https://www.frontiersin.org/articles/10.3389/fsufs. 2020.00117/full\#supplementary-material 
Enete, A., Nweke, F., and Tollens, E. (2002). Contributions of men and women to food crop production labor in Africa: information from COSCA. Outlook Agric. 31, 259-265. doi: 10.5367/000000002101294155

Food and Agriculture Organization of the United Nations (FAO)(1995). A Synthesis Report of the Africa Region - Women, Agriculture and Rural Development. Rome: FAO. Available online at: http://www.fao.org/3/x0250e/ x0250e03.htm\#P146_16018 (accessed July 02, 2019).

Garba, A. S. (2011). Stumbling block for women entrepreneurship in Nigeria: how risk attitude and lack of capital mitigates their need for business expansion. Eur. J. Econ. Finance Adm. Sci. 36, 38-49.

International Labor Organization (ILO) (1998). ILO/SEAPAT's Online Gender Learning and Information Module. Available online at: https://www.ilo.org/ public/english/region/asro/mdtmanila/training/unit1/groles.htm (accessed July 02, 2019).

Jaim, W. M. H., and Hossain, M. (2011). "Women's participation in agriculture in Bengladesh 1988-2008," in Pre-Conference Event on "Dynamics of Rural Livelihoods and Poverty in South Asia", 7th Asian Society of Agricultural Economists (ASAE) International Conference (Hanoi).

Keng Kuek Ser, K. (2016). How Much of Your Work is Unpaid? This Calculator May Help. Available online at: https://www.pri.org/stories/2016-05-07/domesticwork-deserves-salary-and-how-much-we-should-pay-moms (accessed April 01, 2020).

Khachaturyan, M., and Peterson, E. W. F. (2018). "Does gender really matter in agriculture?”. Cornhusker Economics 943. Nebraska, KS: University of Nebraska-Lincoln, 1-3. Available online at: https://digitalcommons.unl.edu/ agecon_cornhusker/943 (accessed April 01, 2020).

Kinkingninhoun, M. F. M., Alidou, A. I., Mujawamariya, G., Saito, K. (2018). Gender Analysis of Rice-Based Farming System in Côte d'Ivoire and Madagascar. Cotonou: Africa Rice.

Kinkingninhoun, M. F. M., Diagne, A., Simtowe, F., Agboh-Noameshie, A. R., and Adégbola, P. Y. (2008). Gender discrimination and its impact on income, productivity, and technical efficiency: evidence from Benin. Agric. Hum. Values 27, 57-69. doi: 10.1007/s10460-008-9170-9

Komatsu, H., Malapit, H. J. L., and Theis, S. (2018). Does women's time in domestic work and agriculture affect women's and children's dietary diversity? Evidence from Bangladesh, Nepal, Cambodia, Ghana, and Mozambique. Food Policy 79, 256-270. doi: 10.1016/j.foodpol.2018.07.002

Lê Cook, B., and Manning, W. G. (2013). Thinking beyond the mean: a practical guide for using quantile regression methods for health services research. Shanghai Arch. Psychiatry 25, 55-59. doi: 10.3969/j.issn.1002-0829.201 3.01.011

Lastarria-Cornhiel, S. (2006). Feminization of Agriculture: Trends and Driving Forces. Paper for The World Development Report, 2008. World Bank, Washington, DC.

Mc Cullough, E. (2017). Labor productivity and employment gaps in Sub-Saharan Africa. Food Policy 67, 133-152. doi: 10.1016/j.foodpol.2016.09.013

Meinzen-Dick, R., and Zwarteveen, M. (1998). Gendered participation in water management: issues and illustrations from water users' associations in South Asia. Agric. Human Values 15, 337-345. doi: 10.1023/A:1007533018254

Moser, C. (1989). Gender planning in the third World: meeting women's practical and strategic needs. World Dev. 17, 1799-1825. doi: 10.1016/0305-750X(89)90201-5

Mujawamariya, G., and Kalema, E. (2017). Limited usage of mechanical equipment in small-scale rice farming: a cause for concern. J. Agric. Environ. Int. Dev. 111, 5-21. doi: 10.12895/jaeid.20171.493
Mwaura, A. T. W., Gathenya, J. W., and Kihoro, J. M. (2015). Dynamics of entrepreneurial orientation on the performance on women owned enterprises in Kenya. Int. J. Acad. Res. Bus. Soc. Sci. 5, 14-34. doi: 10.6007/IJARBSS/v5-i9/1794

Ndindeng, S. A., Manful, J. T., Futakuchi, K., Mapiemfu, D. L., Akoa-Etoa, J. M., Tanga, E. N., et al. (2015). A novel artisanal parboiling technology for rice processors in sub-Saharan Africa. Food Sci. Nutr. 3, 557-568. doi: $10.1002 /$ fsn 3.242

Overholt, C., Anderson, M. B., Cloud, K., and Austin, J. E. (1985). Gender Roles in Development Projects: A Case Book. West Hartford, CT: Kumarian Press.

Padmaja, R., Pramanik, S., Pingali, P., Bantilan, C., and Kavitha, K. (2019). Understanding nutritional outcomes through gendered analysis of time-use patterns in semi-arid India. Glob. Food Secur. 23, 49-63. doi: 10.1016/j.gfs.2019.04.001

Palacios-Lopez, A., Christiaensen, L., and Kilic, T. (2017). How much of the labor in African agriculture is provided by women? Food Policy 67, 52-63. doi: 10.1016/j.foodpol.2016.09.017

Palacios-López, A., and López, R. (2015) The gender gap in agricultural productivity: the role of market imperfections. J. Dev. Stud. 51, 1175-1192. doi: 10.1080/00220388.2015.1028539

Rice Agri-Food System CRP (RICE) (2016). Full Proposal and Flagship Projects. Research Program on Rice. CGIAR.

Sepulveda, J. P., and Bonilla, C. (2014). The factors affecting the risk attitude in entrepreneurship: evidence from Latin America. Appl. Econ. Lett. 2, 573-581. doi: 10.1080/13504851.2013.875104

SOFA Team and Doss, C. (2011). The Role of Women in Agriculture. ESA Working Paper No. 11-02. Agricultural Development Economics Division, The Food and Agriculture Organization of the United Nations, Rome, Italy. Available online at: http://www.fao.org/3/am307e/am307e00.pdf (accessed July 10, 2019).

Tomasz, Z. (2001). Beyond risk seeking and risk aversion: personality and the dual nature of economic risk taking. Eur. J. Pers. 15, 105-122. doi: 10.1002/per.426

United States Department of Agriculture-USDA (2019). Production, Supply and Distribution. Available online at: https://apps.fas.usda.gov/psdonline/app/ index.html\#/app/advQuery (accessed February 03, 2018).

van Koppen, B. (1998). Water rights, gender, and poverty alleviation. Inclusion and exclusion of women and men smallholders in public irrigation infrastructure development. Agric. Human Values 15, 361-374. doi: 10.1023/A:1007537119163

Vepa, S. S. (2005). Feminisation of agriculture and marginalisation of their economic stake. Econ. Polit. Wkly. 40, 2563-2568. doi: 10.2307/4416785

Zwarteveen, M. (1997). Water: from basic need to commodity: a discussion on gender and water rights in the context of irrigation. World Dev. 25, 1335-1349. doi: 10.1016/S0305-750X(97)00032-6

Conflict of Interest: The authors declare that the research was conducted in the absence of any commercial or financial relationships that could be construed as a potential conflict of interest.

Copyright (c) 2020 Kinkingninhoun Medagbe, Komatsu, Mujawamariya and Saito. This is an open-access article distributed under the terms of the Creative Commons Attribution License (CC BY). The use, distribution or reproduction in other forums is permitted, provided the original author(s) and the copyright owner(s) are credited and that the original publication in this journal is cited, in accordance with accepted academic practice. No use, distribution or reproduction is permitted which does not comply with these terms. 